\title{
IRELAND IN THE MIDDLE AGES
}




\title{
British History in Perspective General Editor: Jeremy Black
}

\author{
Eugenio Biagini Gladstone
}

D.G. Boyce The Irish Question and British Politics, 1868-1996 (2nd edn)

Keith M. Brown Kingdom or Province? Scotland and the Regal

Union, 1603-1715

A.D. Carr Medieval Wales

Eveline Cruickshanks The Glorious Revolution

Anne Curry The Hundred Years War

Susan Doran England and Europe in the Sixteenth Century

Sean Duffy Ireland in the Middle Ages

David Gladstone The Twentieth-Century Welfare State

Brian Golding Conquest and Colonisation: the Normans in Britain, 1066-1100 (rev. edn)

Sean Greenwood Britain and the Cold War, 1945-91

David Harkness Ireland in the Twentieth Century: Divided Island

Ann Hughes The Causes of the English Civil War (2nd edn)

I.G.C. Hutchison Scottish Politics in the Twentieth Century

Ronald Hutton The British Republic, 1649-1660 (2nd edn)

T.A. Jenkins Disraeli and Victorian Conservatism

T.A. Jenkins Sir Robert Peel

H.S. Jones Victorian Political Thought

D.E. Kennedy The English Revolution, 1642-1649

John F. McCaffrey Scotland in the Nineteenth Century

A.P. Martinich Thomas Hobbes

Roger Middleton The British Economy since 1945

W.M. Ormrod Political Life in Medieval England, 1300-1450

Richie Ovendale Anglo-American Relations in the Twentieth Century

lan Packer Lloyd George

Keith Perry British Politics and the American Revolution Murray G.H. Pittock Scottish Nationality Murray G.H. Pittock Jacobitism

A.J. Pollard The Wars of the Roses (2nd edn)

David Powell British Politics and the Labour Question, 1868-1990

Richard Rex Henry VIII and the English Reformation

G.R. Searle The Liberal Party: Triumph and Disintegration, 1886-1929 (2nd edn)

John Stuart Shaw The Political History of Eighteenth-Century Scotland

W.M. Spellman John Locke

William Stafford John Stuart Mill

Bruce Webster Medieval Scotland

Ann Williams Kingship and Government in Pre-Conquest England

Ian S. Wood Churchill

John W. Young Britain and European Unity, 1945-99 (2nd edn)

Please note that a sister series, Social History in Perspective, is available covering the key topics in social and cultural history.

\section{British History in Perspective}

Serles Standing Ordar: ISEN 0-333-71356-7 herdoover/SSEN 0-333-69331-0 paperback

You can receive future titles in this series as they are published by placing a standing order. Please contact your bookseller or, in case of difficulty, write to the address

below with your name and address, the title of the series and the ISBN quoted above.

Customer Services Department, Macmillan Distribution Ltd

Houndmills, Basingstoke, Hampshire RG21 6XS, England 


\section{IRELAND IN THE MIDDLE AGES}

SEÁN DUFFY 
All rights reserved. No reproduction, copy or transmission of this publication may be made without written permission.

No paragraph of this publication may be reproduced, copied or transmitted save with written permission or in accordance with the provisions of the Copyright, Designs and Patents Act 1988, or under the terms of any licence permitting limited copying issued by the Copyright Licensing Agency, 90 Tottenham Court Road, London WIP 9HE.

Any person who does any unauthorised act in relation to this publication may be liable to criminal prosecution and civil claims for damages.

The author(s) has/have asserted his/her/their rights to be identified as the author(s) of this work in accordance with the Copyright, Designs and Patents Act 1988.

First published 1997 by

\section{MACMILLAN PRESS LTD}

Houndmills, Basingstoke, Hampshire RG21 6XS

and London

Companies and representatives

throughout the world

ISBN 978-0-333-60620-9

ISBN 978-1-349-25171-1 (eBook)

DOI 10.1007/978-1-349-25171-1

A catalogue record for this book is available from the British Library.

This book is printed on paper suitable for recycling and made from fully managed and sustained forest sources.

Published in the United States of America 1997 by

ST. MARTIN'S PRESS, INC.,

Scholarly and Reference Division

175 Fifth Avenue, New York, N.Y. 10010

ISBN 978-0-312-16389-4 (cloth)

ISBN 978- 0-312-16390-8 (paperback) 
For my mother and father 


\section{CONTENTS}

Preface $\quad$ ix

Maps $\quad$ xi

$\begin{array}{ll}\text { Introduction } & 1\end{array}$

1 Dwellers at the Earth's Edge $\quad 7$

2 A Kingdom Unique to Itself? 28

3 Adventus Anglorum $\quad 57$

4 From Kingdom to Lordship 81

5 Colonial Domination and Native Survival 111

6 A Colony in Retreat 134

$\begin{array}{lll}7 & \text { Equilibrium } & 156\end{array}$

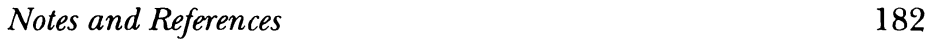

$\begin{array}{ll}\text { Select Bibliography } & 201\end{array}$

$\begin{array}{ll}\text { Index } & 206\end{array}$ 


\section{PREFACE}

This book is not intended to supersede any of the many histories of medieval Ireland already available, several of which are works of such importance that they are likely to remain indispensable to students of the subject for generations to come. However, some of the best work on the subject is out of print, other volumes are by now somewhat dated, and much that remains is work of such formidable scholarship that it is not readily accessible to the beginner. It is for this reason that $I$ have had the temerity to undertake the present volume. Its aims are modest. They are, first, to provide a brief survey of Irish history in the first half of this millennium, written in a style and format that will make this quite difficult subject intelligible to those previously unacquainted with it; second, to incorporate the findings of recent research in the field; and third, to offer - such as it is - my own reinterpretation of the evidence. I hope that this will mean that it contains something of use for both raw recruit and weary veteran alike. There are, however, large gaps in the narrative. I have had limited space to devote to the church, and even less room for society and economy. I can but apologize for this, which is the consequence of trying to cover such a broad time-span in a volume of this size (though in the Bibliography I refer readers to some of the more important works in the field).

Many debts are incurred in compiling a volume even of these dimensions. My primary debt is to all those scholars, living and dead, whose work I have borrowed to build the narrative. I have tried to acknowledge the extent of my indebtedness in the Notes, but I fear that this is not enough. So many 
of the ideas that one thinks are one's own are the product of reading other people's work over the years, or of attending their public lectures, or of conversations with them. Where my theft has gone unacknowledged below I apologize here. Several scholars have had a more direct involvement. Professor James Lydon, Dr Ailbhe Mac Shamhráin, Dr Máire Ní Mhaonaigh, Ms Linzi Simpson and Dr Brendan Smith have read drafts of the book in whole or in part and made many helpful comments. As I have in many instances stubbornly refused to take their advice, the exoneration normally pronounced at this point needs to have even greater force than usual.

The dedication expresses a debt of another kind.

SEÁN DUFFY

Dublin, January 1996 


\section{MAPS}

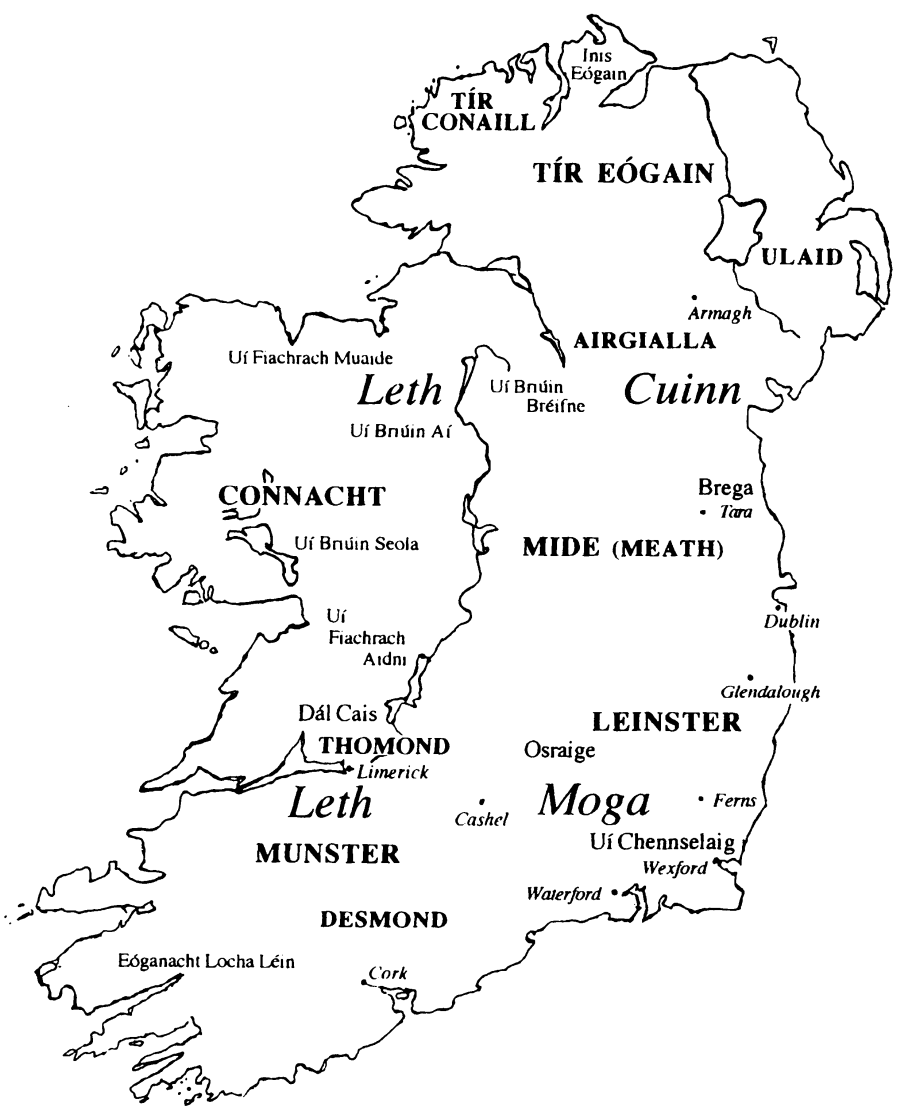

Ireland c. $1000 \mathrm{AD}$

(includes the main place-names and population names mentioned in the text) 


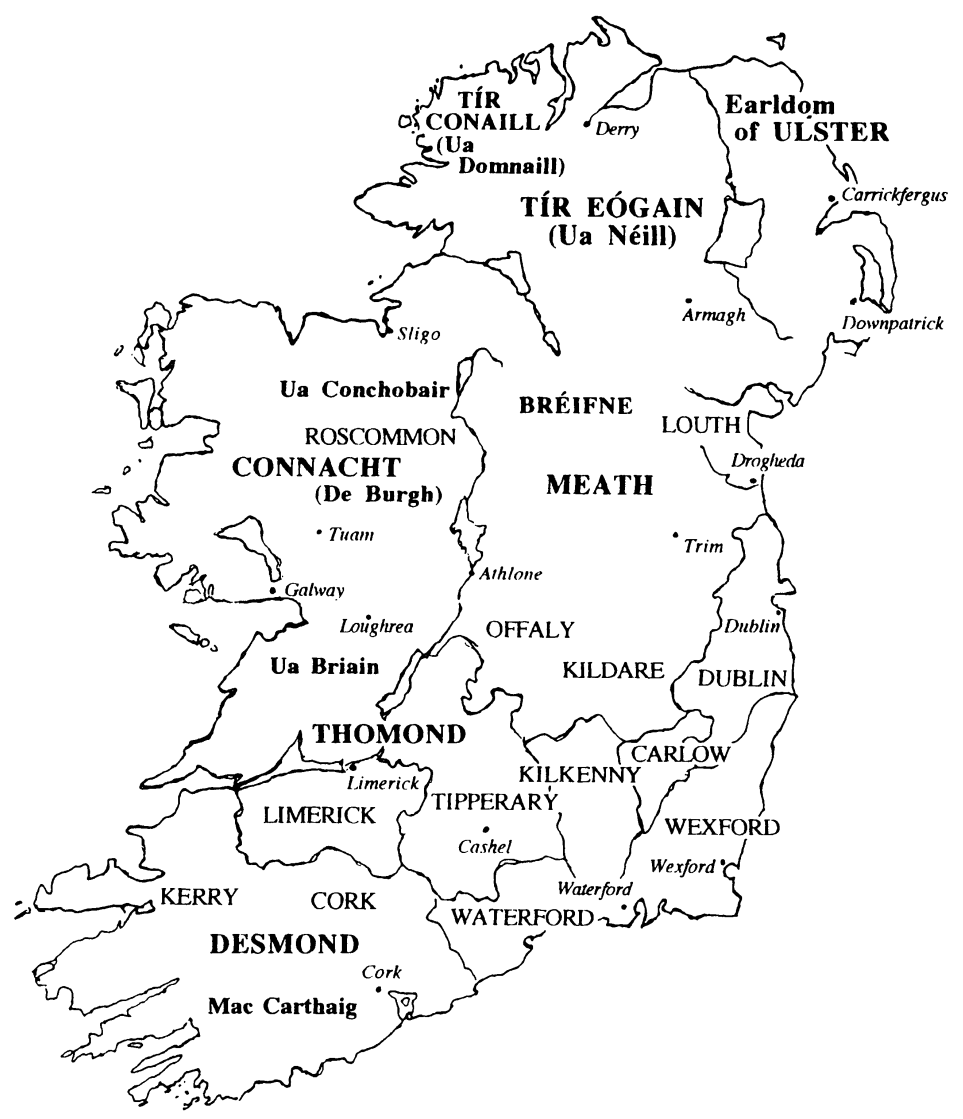

Ireland c. $1250 \mathrm{AD}$

(includes the main place-names and lordships mentioned in the text) 


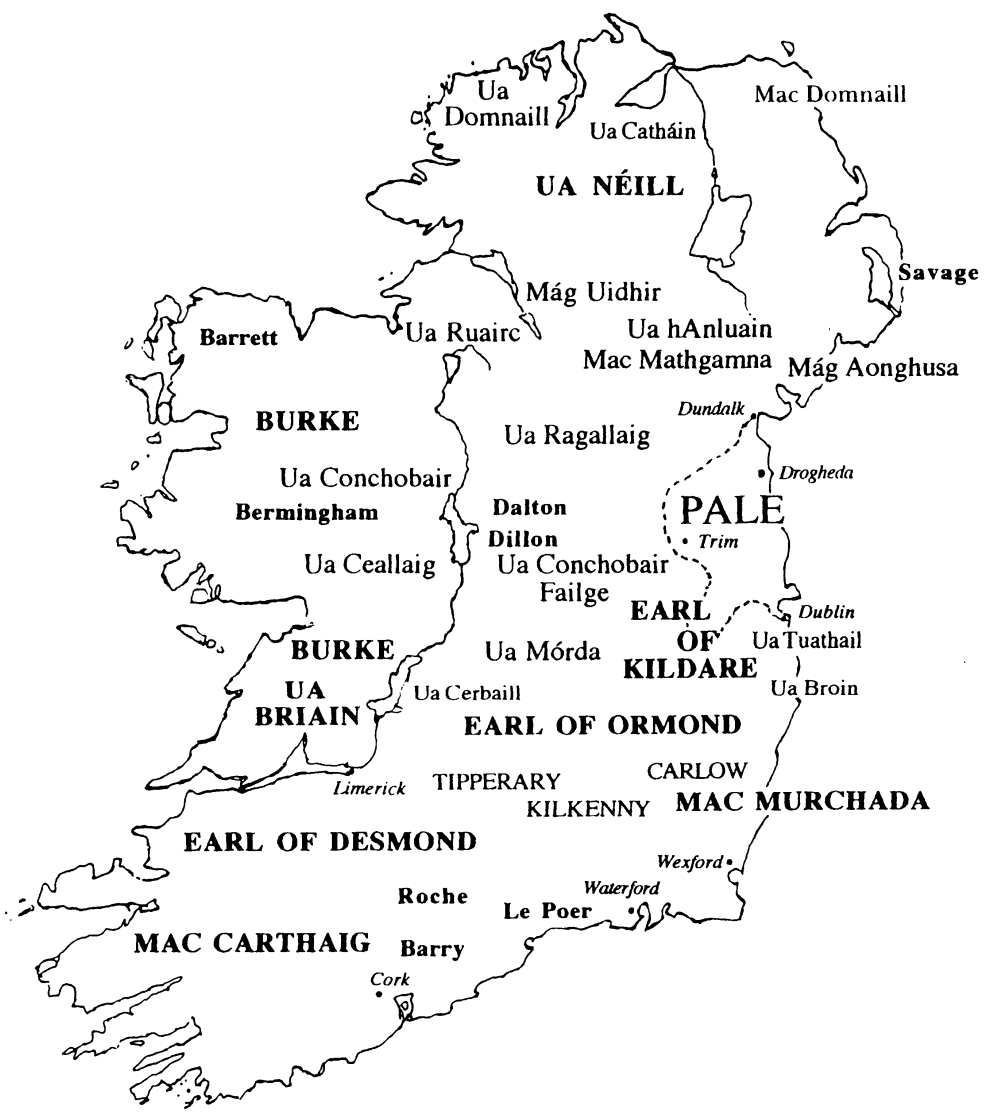

Ireland c. $1500 \mathrm{AD}$

(includes the main place-names and lordships mentioned in the text) 